\title{
Kepuasan Karyawan dalam Konteks Menejemen Perkantoran
}

\section{Oleh:}

\section{*) Idham Khalik}

\section{**)Dosen Tetap Fakultas Ekonomi Universitas Batanghari Jambi}

\begin{abstract}
Abstrak
Manajemen Kantor adalah kegiatan yang dilakukan untuk mengelola, merencanakan, dan mengontrol setiap aktivitas kantor, dimana hasil akhir kegiatan kantor ini berujud pelayanan informasi pada berbagai pihak. Sedangkan beberapa bentuk kegiatan/pekerjaan kantor antara lain: kegiatan catat mencatat, komunikasi, pengumpulan dan penyimpanan informasi(arsip), pelayanan tamu, pelayanan rapat dan lainsebagainya.

Usaha penyelenggaraan kegiatan perkantoran perlu ditangani secara profesiaonal, dalam arti bahwa penyelenggaraan kegiatan perkantoran memerlukan pimpinan dan staff yang mengerti akan tugas fungsinya, bersemangat dalam mengejar prestasi dan seorang karyawan diharapkan dapat mencurahkan perhatiannya secara bersungguh-sungguh, dan berusaha untuk dapat mengolah informasi, sehingga dapat menjadi sesuatu yang berdaya guna.
\end{abstract}

Kata Kunci : Manajemen Kantor, Perkantoran

\section{Pendahuluan}

Menurut James A.F.Stoner, manajemen adalah suatu proses perencanaan, pengorganisasian, kepemimpinan, dan pengendalian upaya anggota organisasi dan menggunakan semua sumber daya organisasi untuk mencapai tujuan yang telah ditetapkan.Dari gambar di atas menunjukkan bahwa manajemen adalah Suatu keadaan terdiri dari proses yang ditunjukkan oleh garis (line) mengarah kepada proses perencanaan, pengorganisasian,kepemimpinan, dan pengendalian, yang mana keempat proses tersebut saling mempunyai fungsi masing-masing untuk mencapai suatu tujuan organisasi. Dapat disimpulkan bahwa

Manajemen Kantor adalah kegiatan yang dilakukan untuk mengelola, merencanakan, dan mengontrol setiap aktivitas kantor, dimana hasil akhir kegiatan kantor ini berujud pelayanan informasi pada berbagai pihak. Sedangkan beberapa bentuk kegiatan/pekerjaan kantor antara lain: kegiatan catat mencatat, komunikasi, pengumpulan dan penyimpanan informasi(arsip), pelayanan tamu, pelayanan rapat dan lainsebagainya.Dalam proses manajemen, sasaran yang ingin diperoleh adalah tercapainya tujuansecara efisien. Apabila 
dalam mencapai tujuan tidak sesuai dengan perencanaan dan dalam proses kegiatannya menimbulkan pemborosan, maka hal tersebut sebaiknya dihindari. Untuk mencegah adanya pemborosan tersebut, maka sumber-sumber daya yang akan dimanfaatkan dalam proses mencapai tujuan itu hendaknya dikelola dengan menerapkanfungsi-fungsi manajemen.

Dalam kehidupan organisasi yang berorientasi pada masa depan, usaha penyelenggaraan kegiatan perkantoran perlu ditangani secara profesiaonal, dalam arti bahwa penyelenggaraan kegiatan perkantoran memerlukan pimpinan dan staff yang mengerti akan tugas fungsinya, bersemangat dalam mengejar prestasi dan seorang karyawan diharapkan dapat mencurahkan perhatiannya secara bersungguh-sungguh, dan berusaha untuk dapat mengolah informasi, sehingga dapat menjadi sesuatu yang berdaya guna. Berdasarkan hal tersebut dapat dikatakan bahwa penyelenggaraan kegiatan perkantoran adalah merupakan inti kehidupan organisasi.

\section{Pengertian Manajemen Kantor}

Manajemen Kantor adalah Perencanaan, pengorganisasian, pengarahan, pengkoordinasian dan pengawasan pekerjaan ketatausahaan untuk mencapai tujuan yang telah diperkirakan.

Manajemen Kantor adalah seluruh kegiatan penataan yang berhubungan dengan pelaksanaan tatausaha sebuah organisasi agar proses tersebut mampu menyediakan informasi yang bermakna bagi proses pembuatan keputusan.Manajemen bukan saja dapat dianggap sebagai suatu jenis ilmu, tetapi juga aktivitas (kegiatan). Sebagai suatu ilmu dan aktivitas, manajemen mempunyai sifat yang unik. Artinya, identitas manajemen berbeda dari ilmu dan aktivitas lainnya.

a. Fungsi Manajemen :

- Perencanaan

- Pengorganisasian

- Pengkoordinasian

- Pengawasan

b. Elemen Manajemen

- Man

- Money

- Material

- Market

- Machine 
- Method (Metode)

Manajemen kantor dapat ditinjau dari dua sudut penglihatan yang berbeda, yaitu dari sudut manajemen dan dari sudut sasaran.

- Dari sudut manajemen, manajemen kantor merupakan kegiatan untuk merencanakan, mengorganisasikan, mengarahkan, mengendalikan, mengoordinasikan, mengawasi, mengurus, menyempurnakan dan menertibkan ketatausahaan kantor.

- Dari sudut sasaran, manajemen kantor merupakan segala kegiatan penataan yang ditujukan kepada segala hal yang berhubungan dengan pelaksanaan tatausaha dalam sistim perkantoran untuk mencapai sasaran organisasi.

Dua sudut penglihatan manajement kantor:

- Dari sudut manajemen : Manajemen kantor merupakan kegiatan untuk merencanakan, mengarahkan, mengendalikan, mengoordinasikan, mengawasi, mengurus, menyempurnakan dan menertibkan tata usaha kantor.

- Dari sudut sasaran: manajemen kantor adalah segala kegiatan penataan yang ditujukan kepada segala hal yang berhubungan dengan pelaksanaan tata usaha dalam sistem perkantoran untuk mencapai sasaran organisasi.

Untuk mengelola suatu pekerjaan agar dapat mencapai hasil yang sesuai dengan tujuan yang ditentukan, sangat memerlukan keahlian khusus, bukan saja keahlian tekhnis, melainkan juga keahlian dalam memimpin orang - orang. Artinya, memotivasi orang lain agar mau bekerja dengan giat dan kreatif. Oleh karena itu, seorang manajer yang berhasil ialah yang mampu menggerakan bawahannya agar berhasil. Dengan kata lain, manajer yang berhasil adalah seseorang yang senantiasa mendorong dan memberi kesempatan kepada bawahannya untuk maju, dalam arti mampu meningkatkan dan mengembangkan keahlian serta pengabdiaan bawahannya

\section{A. Aktivitas dari Manajemen Kantor}

Geoffrey Whitehead mengatakan bahwa di seluruh kantor terdapat lima bidang kegiatan utama, yaitu:

- Kegiatan komunikasi

- Kegiatan kalkulasi 
- Pengolahan Warkat

- Penyusunan laporan

- Kegiatan yang mengikuti prosedur rutin

Pekerjaan manajer dalam menilai dan mengatur pekerjaan yang diselenggarakan yaitu dengan cara pengawasan yang diperoleh melalui:

a. Developing performance standard (perkembangan tingkat/derajat pekerjaan)

b. Measuring performance (pengukuran hasil pekerjaan)

c. Evaluating results (penilain hasil pekerjaan

d. Taking corrective action (pengambilan tindakan perbaikan).

Keempat cara pengawasan melalui manajemen pengendalian dapat dijelaskan sebagai berikut:

a) Develoving performance standard

Pekerjaan yang harus di selesaikan oleh manajer dalam menetapkan alat alat pengukuran (yard - stick). Dengan alat itu, dinilainya hasil pekerjaan orang yang harus melapor padanya

b) Measuring performance

Menetapkan status pekerjaan yang sedang dilaksanakan dan yang telah selesai. Hal ini dapat dicapai melalui pengamatan, laporan dan catatan berbagai kegiatan.

c) Evaluating result

Menetapkan arti perbedaan - perbedaan dan kekecualian - kekecualian dengan cara membandingkan hasil pekerjaan yang sebenarnya dengan ukuran hasil pekerjaan.

d) Taking corrective action

Meluruskan dan mengadakan perbaikan terhadap penyimpangan penyimapangan yang terjadi.

Fungsi pokok manajemen dalam perkantoran yang merupakan pekerjaan manajer seperti berikut:

1. Perencanaan (pleaning)

- Menjelaskan, memantapkan dan memastikan tujuan yang dicapai

- Meramalkan peristiwa atau keadaan pada waktu yang akan dating

- Memperkirakan kondisi - kondisi pekerjaan yang dilakuka 
- Membuat kebijaksanaan, prosedur, standard dan metode - metode untuk pelaksanaan kerja

- Memikirkan peristiwa dan kemungkinan akan terjadi

- Mengubah rencana sesuai dengan petunjuk hasil pengawasan

2. Pengorganisasian (organizing)

- Membagi pekerjaan kedalam tugas - tugas operasional

- Mengelompokan tugas - tugas kedalam posisi - posisi secara operasioanal

- Menggabungkan jabatan - jabatan operasional kedalam unit - unit yang saling berkaitan

- Memilih dan menetapkan orang untuk pekerjaan yang sesuai

- Menjelaskan persyaratan dari setiap jabatan

- Menyesuaikan wewenang dan tanggung jawab bagi setiap anggota

- Menyediakan berbagai fasilitas untuk pegawai

- Menyelaraskan organisasi sesuai dengan petunjuk hasil pengawasan

3. Penggerakan (Actuating)

- Melakukan kegiatan partisivasi dengan senang hati terhadap semua keputusan, tindakan atau perbuatan

- Mengarahkan dan menantang orang lain agar bekerja sebaik - baiknya

- Memotivasi anggota

- Berkomunikasi secara efektif

- Meningkatkan anggota agar memahami potensinya secara penuh

- Memberikan imbalan penghargaan terhadap pekerja yang melakukan pekerjaan dengan baik

- Mencukupi keperluan pegawai sesuai dengan kegiatan pekerjaannya

\section{Pengendalian (controllig)}

- Berupaya memperbaiki pengarahan sesuai dengan petunjuk pengawasan

- Membandingkan hasil - hasil pekerjaan dengan rencana secara keseluruhan

- Menilai hasil pekerjaan dengan standard hasil kerja

- Membuat media pelaksanaan secara tepat

- Memberitahukan media pengukur pekerjaan 
- Memindahkan data secara terperinci agar dapat terlihat perbandingan dan penyimpangan - penyimpangannya

- Membuat saran tindakan - tindakan perbaikan jika dirasa oleh anggota

- Memberitahu anggota - anggota yang bertanggung jawab terhadap pemberian penjelasan

- Melaksanakan pengawasan sesuai dengan petunjuk hasil pengawasan.

\section{B. Proses Manajemen Kantor}

a) Perencanaan kantor

Meliputi segala aktivitas peramalan mengenai hal ihwal yang harus dilakanakan dana cara-cara pelaksanaannya dalam bidang tata usaha kantor. Maksud perencanaan kantor adalah mencapai efesien yang tertinggi dalam pelaksanaan tata usaha tersebut.

b) Pengorganisasian kantor

- Suatu proses penyusunan kerja sama antara elemen-elemen kantor untuk mencapai tujuan tertentu.

- Adalah suatu sistim kerja sama yang meliputi pola pembagian kerja, susunan hubungan kerja, lalu lintas wewenang dan tanggung jawab antara para petugas dan struktur hubungan tersebut.

c) Pengoordinasian kantor

Merupakan suatu kegiatan untuk menjamin kerja sama dan partisipasi sejumlah kegiatan kantor Pengawasan kantor (Pengendalian).

d) Tujuan kantor

- Penerimaan Informasi

- Pencatatan informasi

- Penyusunan informasi

- Pemberian Informasi

- Perawatan aktiva

e) Aspek manajemen kantor

- Tujuan, yang dapat dirumuskan untuk menilai dan menetapkan keberhasilan mengarahkan dan mengkoordinasian elmen-elemen manajemen

- Organisasi, meliputi kegiatan pembentukan staf dan alokasi tugas untuk staf tersebut

- Metode adalah urutan pelaksanaan bagaimana dana di mana pelaksanaan manajemen dilangsungkan 
- Personalia, meliputi perekrutan staf, tempat, latihan, dan pengehntian karyawan

- Lingkungan, meliputi bangunan kantor, perabot dan kondisi jasmani di dalam kantor

- Mesin dan perlengkapan, mencakup segenap benda mati yang digunakan dalam kantor untuk membantu pelaksanaan kerja.

f) Harapan manajemen kepada manajemen kantor

- Manajer kantor hendaknya menjadi seorang pengorganisasi

- Manajer kantor hendaknya menjadi seorang pemimpin dinamis

- Manajer kantor hendaknya dapat memperoleh dan melatih pekerja-pekerja kunci dan asisten-asisten untuk mengawasi pekerjaan di bawah pengawasannya

- Manajer kantor hendaknya menyisihkan waktu untuk mengembangkan dirinya dan mengembangkan sifat-sifat kepribadiannya yang merupakan karanter eksekutif yang berhasil

- Manajer kantor hendaknya dapat mermalkan, membayangkan dan merencanakan pemecahan masalah kantor yang akan terjadi hari esok.

g) Peranan manajemen kantorMenyiapkan informasi agar manajemen puncak dapat membuat keputusan Informasi tersebut harus :

- Ringkas (concise)

- Cermat (accurate)

- Dalam bentuk yang tepat (in the correct form)

- Tepat waktu (right time)

- Biaya rendah (low cost)

\section{Perumusan Organisasi}

Organisasi yang merupakan usaha dari manusia itu segala kebutuhannya tidaklah mungkin ada bila tidak ada intraksi antara anggota - anggota karyawan atau masyarakat yang mewujudkan organisasi kerja itu.

1. Struktur Organisasi - Organisasi Sederhana

- Manajer Umum

- Petugas Pembeliaan

- Manajer Produksi

- Manajer Pemasaran

2. Manajer kantor organisasi yang telah berkembang

- Direktur Pengelola 
- Petugas Pembeliaan

- Manajer Produksi

- Manajer Pemasaran

\section{Pendekatan Fungsional dalam organisasi}

a) Sentralisasi

Untuk meningkatkan efisiensi, semua pekerjaan kantor harus dikoordinasi oleh seorang manajer kantor, walaupun beberapa bagian darinya dapat dikerjakan di dalam kantor-kantor departemen yang tidak berada di bawah pengawasannya. Didalam beberapa organisasi, manajer kantor utama diberi tanggung jawab penuh atas semua kantor, termasuk yang terkait dengan departemen operasi. Ia diminta untuk mengorganisasi, memperlengkapi, mengangkat staf dan memanajemenkan kantor-kantor ini dengan memberikan pelayanan seperti yang mungkin diminta oleh manajer departemen atau fungsional.

b) Desentralisasi

c) Manajer Umum

d) Petugas Pembelian

e) Manajer Produksi

f) Manajer Pemasaran

g) Manajer kantor

h) Kantor pembelian

i) Kantor pabrik sio

\section{E. Pembagian Kerja dan Penugasan Kerja}

a) Delegasi

Adalah proses dimana individu atau kelompok memindahkan kepada individu atau kelompok lain tugas untuk menjalankan aksi tertentu dan sekaligus mengambil keputusan tertentu.

Delegasi dapat dinyatakan secara ringkas sebagai suatu proses dimana seorang manajer :

- Menyerahkan tugas kepada bawahannya.

- Memberi mereka wewenang untuk membuat komitmen sampai batas yang dianggap perlu untuk memungkinkan tugas dikerjakan. 
- Menciptakan kewajiban pada pihak setiap bawahan untuk melaksanakan pekerjaan secara memuaskan.

b) Analisis pekerjaan

Adalah proses penelitian tugas kantor

- Langkah-langkahnya: Menentukan pembagian pekerjaan secara umum di dalam kantor

- Pembagian tugas: Menurut fungsi dan menurut proses

\section{Kesimpulan}

Manajemen Kantor adalah kegiatan yang dilakukan untuk mengelola, merencanakan, dan mengontrol setiap aktivitas kantor, dimanahasil akhir kegiatan kantor ini berujud pelayanan informasi pada berbagai pihak. Sedangkan beberapa bentuk kegiatan/pekerjaan kantor antara lain: kegiatan catat mencatat, komunikasi, pengumpulan dan penyimpanan informasi(arsip), pelayanan tamu, pelayanan rapat dan lainsebagainya.

Manajemen Perkanotran dapat di nyatakan sebagai "Kekuatan yang tidak berwujud, yang merencanakan, mengorganisasikan da mengkoordonasikan manusia, bahanbahan, mesin-mesin, uang dan pasar-pasar dalam bidang pekerjaan kantor dan mengarahkan dan mengawasi aneka macam hal demikian rupa, hingga dicapai sasaran perusahaan”.

\section{Daftar Pustaka}

http://mbegedut.blogspot.com/2012/06/pengertian-manajemen-perkantoran.html http://wartawarga.gunadarma.ac.id/.../pengertian-manajemen-perkantoran/ http://www.artikelekonomi.net/2011/pengertian-manajemen-perkantoran/ http://bebekaja-funie.blogspot.com/2007/07/informasi-dan-artikel-tips-tentang.html http://thisismeyunus.wordpress.com/2012/01/09/pendekatan-pendakatan-manajemenperkantoran/

http://30agustus2003.blogspot.com/2012/04/manajemen-perkantoran.html 